\title{
Genetic variation in continental and island populations of Eichhornia paniculata (Pontederiaceae)
}

\author{
D. E. Glover* and \\ S. C. H. Barrett
}

Department of Botany, University of Toronto, Toronto, Ontario, Canada M5S 1A1

Genetic variation was examined at 21 allozyme loci in 11 populations of Eichhornia paniculata (Pontederiaceae) from N.E. Brazil and Jamaica. Populations from Jamaica are genetically depauperate with respect to electrophoretically detectable variation, containing a significantly lower number of polymorphic loci, alleles per locus, mean observed heterozygosity and genetic diversity than Brazilian populations. These measures were significantly correlated with the outcrossing rate $(t)$ of populations. The allozyme data were used to examine the patterns of genetic variation within and between populations by estimates of gene correlation and Nei's gene diversity statistics. Populations within both regions are highly differentiated from one another, with those from Jamaica more strongly so. Brazilian populations contain more variation than is distributed among populations, while the reverse pattern occurs among Jamaican populations. The genetic distance between Jamaican populations is less than between Brazilian populations as a result of the low overall variability on the island. It is proposed that the founding of populations on Jamaica by longdistance dispersal, genetic drift and high levels of self-fertilisation all contribute to reducing levels of genetic variation in Jamaican populations.

\section{INTRODUCTION}

Floristic and faunistic studies of islands have been frequent, particularly with regard to factors that influence adaptive radiation and speciation, degree of endemism and community organization (Darlington, 1957; MacArthur and Wilson, 1967; Carlquist, 1974; Lack, 1976; Williamson, 1981). Because opportunities for gene flow are often reduced and island habitats may be ecologically as well as geographically marginal, island populations can act as natural experiments of the effects of isolation and directional selection on the genetic structure of populations. Comparison of continental and island populations in several animal groups have provided particularly valuable insights into evolutionary processes (Dobzhansky, 1957; Clarke and Sheppard, 1963; Avise et al., 1974; Ayala et al., 1971). Despite their vagrancy and capacity for long-distance dispersal, there have been few studies of the ecological genetics of continental and island population of plants. With this in mind, the present study was designed to contrast the

* Present address: Department of Botany and Plant Sciences, University of California, Riverside, California 92521, U.S.A. levels of genetic variability and degree of genetic differentiation in continental and island populations of the diploid, tristylous, emergent aquatic Eichhornia paniculata (Pontederiaceae).

Eichhornia paniculata has a markedly disjunct geographical distribution. Populations are numerous throughout the states of N.E. Brazil, also occur on the Caribbean islands of Cuba and Jamaica and isolated populations are reported from Nicaragua and W. Brazil (Barrett, 1985a; Glover and Barrett, 1986). The founding and establishment of populations in the Caribbean region likely resulted from long-distance dispersal, although the direct source area and time of colonisation is unknown. Nevertheless, because such dispersal events are likely to be infrequent, it may be predicted that populations on the island of Jamaica should display lower levels of genetic variation than populations from N.E. Brazil. Data on the distribution of style morphs in E. paniculata is consistent with this suggestion. While populations in N.E. Brazil most commonly contain the three style morphs, on Jamaica the short-styled morph is absent, and self-pollinating semi-homostylous variants of the mid-styled morph predominate 
(Barrett 1985a,b). Absence of the short-styled morph from Jamaica is indicative of a genetic bottleneck associated with island colonisation. Selfing forms would be favoured in establishment on Jamaica following long-distance dispersal.

In this study, allozyme data are used to examine gene diversity and patterns of genetic differentiation between 11 populations from the two regions. Since populations within and between the two regions also vary in floral morphology (Barrett, 1985a) and mating system (Barrett et al., 1987; Glover and Barrett, 1986), an additional objective of the study was to examine whether differences in the mating systems of populations are associated with contrasting genetic structures.

\section{MATERIALS AND METHODS}

\section{Sites and sampling}

Seed families were collected in May-June 1982 from 6 populations of Eichhornia paniculata in
N.E. Brazil (B) and 5 populations from Jamaica (J) during January 1983. Populations sampled in N.E. Brazil were chosen to represent the range of floral morph structures (trimorphic: long-, midand short-styled morphs, hereafter $\mathrm{L}, \mathrm{M}$, and $\mathrm{S}$, respectively; dimorphic: $\mathrm{L}, \mathrm{M}$; and monomorphic: M) observed for the region, whereas in Jamaica all populations encountered during the 1983 season were sampled. The distribution of populations are mapped in figure 1 and information on locality, morph structure and outcrossing rate are presented in table 1. Further details of the habitat, population size and floral biology of populations are given in Glover and Barrett (1986).

\section{Electrophoretic procedures}

Horizontal starch gel electrophoresis was used to obtain allozyme data for 11 enzyme systems. An initial screening of plant tissues indicated that enzyme activity was consistently highest in mature buds, and as a result this tissue was used in all

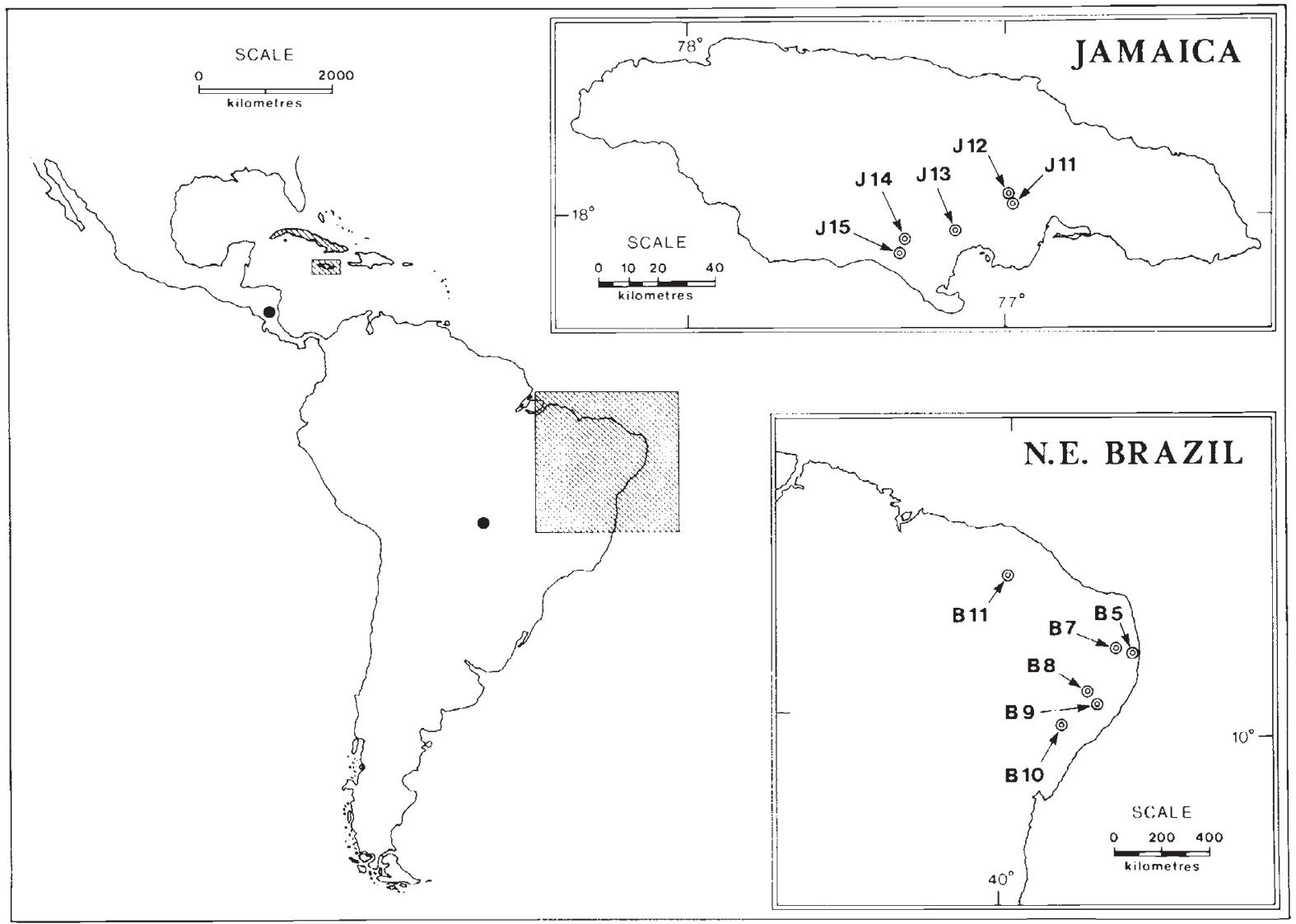

Figure 1 Distribution of Eichhornia paniculata and location of populations studied in N.E. Brazil and Jamaica. Isolated populations are reported from Nicaragua and W. Brazil. 
Table 1 Location, morph structure and multilocus estimates of outcrossing rate $(t)$ in populations of Eichhornia paniculata from N.E. Brazil and Jamaica. Data on outcrossing rates and their standard errors are from Glover and Barrett $(1986)$. T $=$ trimorphic, $\mathrm{D}=$ dimorphic, $\mathrm{M}=$ monomorphic for style morph

\begin{tabular}{|c|c|c|c|c|}
\hline Designation & Locality & $\begin{array}{l}\text { Morph } \\
\text { structure }\end{array}$ & $\begin{array}{l}\text { Outcrossing } \\
\text { rate }(t)\end{array}$ & S.E. \\
\hline B5 & Recife, Pernambuco, Brazil & $\mathbf{T}$ & 0.96 & 0.025 \\
\hline B11 & Quixadá, Ceará, Brazil & $\mathrm{T}$ & 0.94 & 0.023 \\
\hline B9 & União dos Palmares, Alagoas, Brazil & $\mathrm{D}$ & $0 \cdot 49$ & 0.027 \\
\hline $\mathrm{B} 10$ & Arapiraca, Alagoas, Brazil & $\mathrm{D}$ & 0.77 & 0.067 \\
\hline $\mathrm{J} 14$ & Rhymsbury, Clarendon, Jamaica & D & $0 \cdot 29$ & 0.070 \\
\hline $\mathrm{J} 12$ & Angels, St. Catherine, Jamaica & D & 0.47 & 0.090 \\
\hline $\mathrm{J} 11$ & Angels, St. Catherine, Jamaica & $\mathbf{M}$ & $\sim^{*}$ & - \\
\hline $\mathrm{J} 13$ & Rosewell, Clarendon, Jamaica & M & - $^{*}$ & - \\
\hline
\end{tabular}

* No isozyme variation detected at 21 loci; plants autogamous.

assays. Three buds from an individual plant were placed in a well of a glass grinding tray and homogenised in 3 drops of extraction buffer $\left(0.05 M \mathrm{~K}_{2} \mathrm{HPO}_{4}\right.$ with $1 \mathrm{mg} / \mathrm{ml}$ of dithiothreitol) to which a spatula tip of PVPP (polyvinylpolypyrrolidone) was added. The homogenate was absorbed onto filter paper wicks and loaded with the aid of forceps into a slit cut along the cooled gel.

Gels were prepared with Sigma starch at an 11 per cent $w / v$ concentration and $10 \mathrm{~g}$ sucrose. Three buffer systems were used: (A) Continuous Histidine citrate, $p \mathrm{H} 6.5$ (Cardy et al., 1981), (B) Discontinuous Li-borate/Tris-citrate, $p \mathrm{H} \quad 8 \cdot 3$ (Cardy et al., 1981), (C) Discontinuous Poulik, $p \mathrm{H}$ 8.3-8.6/7.9 (modified from Mitton et al., 1977). Electrophoresis was conducted in a glass front refrigerator at $0-4^{\circ} \mathrm{C}$. Wicks were removed after 10 minutes. The voltages maintained for the different buffer systems were as follows:

$\begin{array}{lllll}\begin{array}{l}\text { Buffer } \\ \text { system }\end{array} & \text { Voltage } & \mathrm{mA} & \begin{array}{l}\text { Running } \\ \text { time }\end{array} & \begin{array}{l}\text { Front } \\ \text { migration }\end{array} \\ \text { A } & 400-475 & 50 & 6 \mathrm{~h} & 9.5 \mathrm{~cm} \\ \text { B } & 180-250 & 50 & 5 \mathrm{~h} & 8.0 \mathrm{~cm} \\ \text { C } & 125-175 & 50 & 5 \mathrm{~h} & 8.0 \mathrm{~cm}\end{array}$

A standard $375 \mathrm{ml}$ gel provided 6 slices (each $1.5 \mathrm{~mm}$ thick). The top and bottom slices were discarded, and the remaining slices were placed in styrofoam trays for staining. Table 2 lists the enzyme systems stained, the number of loci scored, the buffer systems used and references for staining procedures. Gels were scored immediately following incubation and soaked overnight in a $5: 5: 1$ solution of methanol: water: glacial acetic acid for preservation.

Table 2 Enzymes, number of loci and buffer systems used during study of Eichhornia paniculata

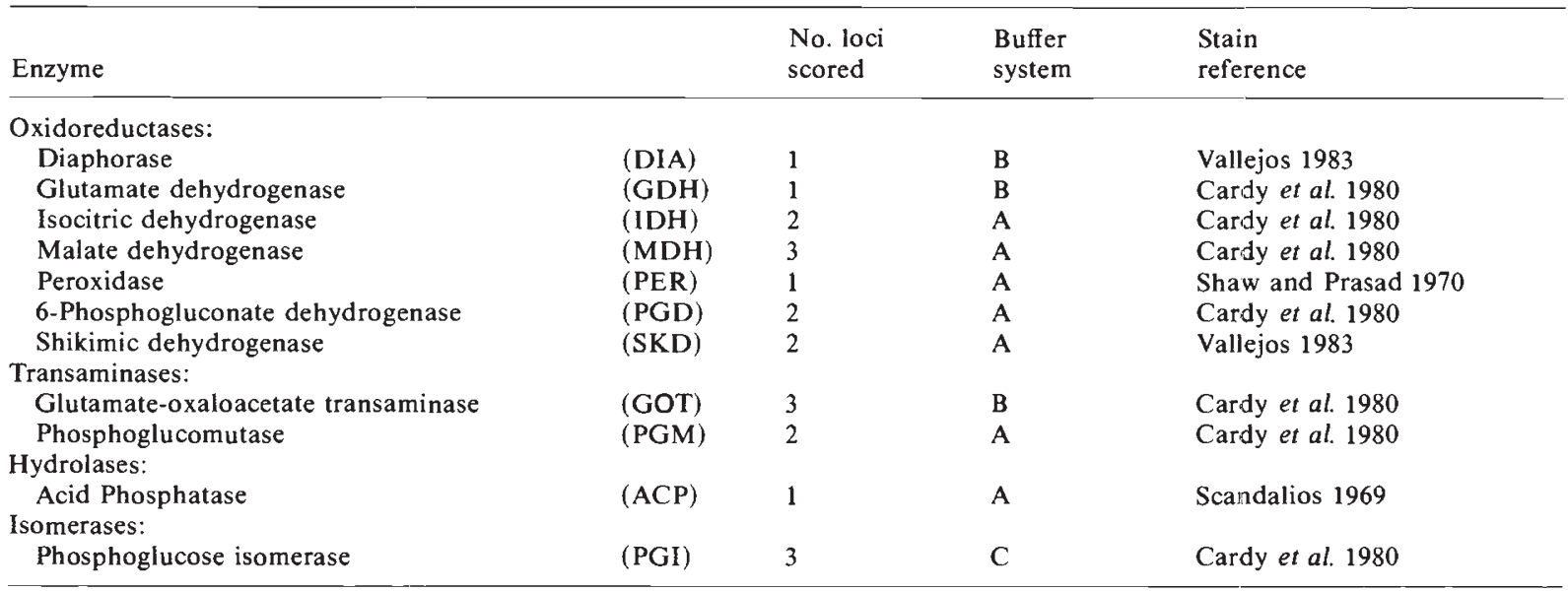


For a given enzyme system the locus coding for the most anodally migrating protein was designated 1 , the next 2 , and so on. Allozymes and their corresponding alleles are identified by a lower case letter. The allele coding for the most anodally migrating allozyme was designated $a$, the next $b$, and so on. Inheritance studies that confirm the genetic models that account for the observed isozyme variation are detailed in Glover (1985) and S. C. H. Barrett (unpublished data). In population B11, several patterns that were not easily interpreted were observed at MDH-2. Because segregation analysis of crosses is not completed, this population was left out of all analyses that included MDH-2. For PGI-3 a null allele was detected in populations B5, B9 and B10. Heterozygotes involving the null allele were indistinguishable from homozygotes $a a$ or $b b$. Without extensive progeny testing of populations in which the null allele occurs, the frequency of alleles $a, b$, and $n$ cannot be determined. Accordingly, these populations were omitted from analyses that included PGI-3.

\section{Population structure}

Three parameters that summarise population structure were introduced by Wright (1951); $F_{\mathrm{IT}}$, $F_{\mathrm{ST}}$ and $F_{\mathrm{IS}}$. An analysis of variance estimation approach to these parameters has been advocated by Weir and Cockerham (1984) and is used here. After consideration of bias introduced when unequal and finite sample sizes, multiple alleles and multiple loci are not accounted for, and in the interest of standardising estimators, they present a more robust set of parameters related to $F$. statistics such that $F \simeq F_{\mathrm{IT}}, \theta \simeq F_{\mathrm{ST}}$, and $f \simeq F_{\mathrm{IS}}$ (Cockerham, 1969, 1973). $F$ describes the correlation of genes within individuals and is approximately the fixation index in the total population, $\theta$ describes the correlation of genes between individuals within populations and measures the differentiation between populations. The correlation of genes within individuals in a given population is denoted by $f$, which describes the relationship of the observed heterozygosity to that expected under panmixia (Hardy-Weinberg equilibrium) and is approximately equivalent to Wright's fixation index. The parameters are related by $f=$ $(F-\theta) /(1-\theta)$. Computational formulas are given in Weir and Cockerham (1984). The variance of the estimators when multiple loci are used can be approximated by the jackknife procedure (Miller, 1974), omitting one locus at a time and calculating the variance among the resulting estimates.

\section{Gene diversity}

The degree of gene differentiation when population structure is hierarchical can be analysed using Nei's gene diversity statistics (Nei, 1973). The gene diversity in the total population, $H_{T}$, is given by $H_{T}=H_{S}+D_{S T}$ where $H_{S}$ is the gene diversity within subpopulations and $D_{S T}$ the gene diversity between subpopulations. The gene diversity between populations, $G_{S T}$, relative to that of the total assemblage of populations, is given by $G_{S T}=$ $D_{S r} / H_{T}$. The inter-populational gene diversity relative to the intra-populational gene diversity is given by $R_{S T}$, where $R_{S T}=\bar{D}_{m} / H_{S}$ and $\bar{D}_{m}$ is a measure of within subpopulation diversity calculated from $D_{S T}$ by excluding the comparisons of subpopulations with themselves. These statistics can be measured using data from one or more loci. Nei and Roychoudhury (1974) advocate the use of a large number of randomly chosen loci that include both polymorphic and monomorphic loci. Data from all loci were included in this analysis.

\section{RESULTS}

\section{Allelic richness and observed heterozygosity}

Among the 11 populations of E. paniculata, a total of 21 loci were scored. Of these, 13 were polymorphic in at least one population. Allele frequencies for polymorphic loci are presented in the Appendix. The remaining eight loci (IDH-1, IDH-2, MDH-1, PGD-2, SKD-1, SKD-2, PGM-2, PGI-1) were monomorphic in all populations examined.

In Brazilian populations, 36 alleles were detected among the 21 loci compared to 24 alleles in Jamaican populations. The representation of alleles in Jamaica is moderately differentiated from a simple subset of alleles sampled from Brazil. Of the total array of alleles in all populations, 46.3 per cent were shared by the two regions. Thus 17 (47 per cent) of the Brazilian alleles were found only in that region, while 5 (21 per cent) of the Jamaican alleles were diagnostic for the island. Two of the three polymorphic loci in Jamaica were invariant in all Brazilian populations. Of the 9 loci that were monomorphic in Jamaica but polymorphic in Brazil, 6/9 were fixed for the most common Brazilian allele, $1 / 9$ was fixed for the least common allele, and 2/9 were fixed for alleles only recorded from Jamaica.

The mean number of alleles per locus $(\bar{K}$, where the frequency of the least common allele is $>0.05)$, the percentage of loci polymorphic $(P$, where a locus is polymorphic when the frequency of the 
most common allele is $<0.95$ ) and the mean observed proportion of loci at which an individual is heterozygous $\left(\bar{H}_{0}\right.$, scored by direct count) are presented in table 3 for each population, with the regional mean for each value. Overall, $\bar{K}$ ranged from 1.0 to $1.45, P$ ranged from 0 to 35 , and $\bar{H}_{0}$ ranged from 0 to $12 \cdot 0$. Brazilian populations are significantly richer in alleles than Jamaican populations as measured by $\bar{K}(t=2 \cdot 99, \mathrm{df}=9, p<$ $0.02)$ and $P(t=2.86, \mathrm{df}=9, p<0.05)$. In addition, individuals in Brazilian populations are on average more heterozygous than individuals in Jamaican populations $(t=2 \cdot 94, \mathrm{df}=9, p<0 \cdot 05)$. Two populations $(\mathrm{J} 11, \mathrm{~J} 13)$ were invariant at all 21 allozyme loci. At two of the three loci at which variation was detected in Jamaica, the populations were fixed for different alleles.

Table 3 Mean number of alleles per locus $(\bar{K})$, per cent of loci polymorphic $(P)$, and mean observed heterozygosity $\left(\bar{H}_{0}\right)$, in populations of Eichhornia paniculata from N.E. Brazil and Jamaica

\begin{tabular}{|c|c|c|c|c|}
\hline Population & $\begin{array}{l}\text { No. of } \\
\text { loci }\end{array}$ & $\bar{K}(\mathrm{SD})$ & $P L P P$ & $\bar{H}_{\mathrm{o}}(\mathrm{SD})$ \\
\hline \multicolumn{5}{|l|}{ Brazil } \\
\hline B5 & 20 & $1.45(0.67)$ & $35 \cdot 0$ & $11 \cdot 3(18 \cdot 6)$ \\
\hline B7 & 21 & $1.24(0.53)$ & $19 \cdot 0$ & $7 \cdot 8(15 \cdot 9)$ \\
\hline B11 & 20 & $1.35(0.57)$ & $30 \cdot 0$ & $12.0(19.9)$ \\
\hline B9 & 20 & $1.30(0.46)$ & $30 \cdot 0$ & $7 \cdot 0(11 \cdot 4)$ \\
\hline B 10 & 20 & $1.25(0.43)$ & $25 \cdot 0$ & $7.9(13.9)$ \\
\hline B8 & 21 & $1.05(0.21)$ & $4 \cdot 7$ & $0.8(3 \cdot 2)$ \\
\hline Mean & & $1.27(0.37)$ & $23 \cdot 8$ & $7 \cdot 8(1.98)$ \\
\hline \multicolumn{5}{|l|}{ Jamaica } \\
\hline $\mathrm{J} 15$ & 21 & $1 \cdot 14(0.35)$ & $14 \cdot 3$ & $5 \cdot 0(12 \cdot 3)$ \\
\hline $\mathrm{J} 14$ & 21 & $1 \cdot 14(0 \cdot 35)$ & $14 \cdot 3$ & $2 \cdot 3(5 \cdot 9)$ \\
\hline $\mathrm{J} 12$ & 21 & $1.09(0.29)$ & $9 \cdot 5$ & $2 \cdot 5(8 \cdot 0)$ \\
\hline $\mathrm{J} 11$ & 21 & $1.00(0.0)$ & 0.0 & $0.0(0.0)$ \\
\hline $\mathrm{J} 13$ & 21 & $1.00(0.0)$ & $0 \cdot 0$ & $0.0(0 \cdot 0)$ \\
\hline Mean & & $1.07(0.27)$ & $7 \cdot 6$ & $2 \cdot 0(1 \cdot 4)$ \\
\hline
\end{tabular}

Multilocus estimates of outcrossing rate, using the method of Ritland and Jain (1981), have been calculated for nine of the 11 populations (Glover and Barrett, 1986); the exceptions are the two invariant populations. Outcrossing rate $(t)$ was significantly rank correlated with $\bar{K}\left(r_{\mathrm{s}}=0.788\right.$, $n=9, p=0.012), P\left(r_{\mathrm{s}}=0.758, n=9, p=0.018\right)$ and $\bar{H}_{0}\left(r_{\mathrm{s}}=0.900, n=9, p=0 \cdot 001\right)$ (fig. 2).

\section{Population structure}

Table 4 presents estimates of gene correlation for E. paniculata populations in N.E. Brazil and Jamaica. For N.E. Brazil, the significant, positive $\hat{F}$ value indicates a correlation of genes within
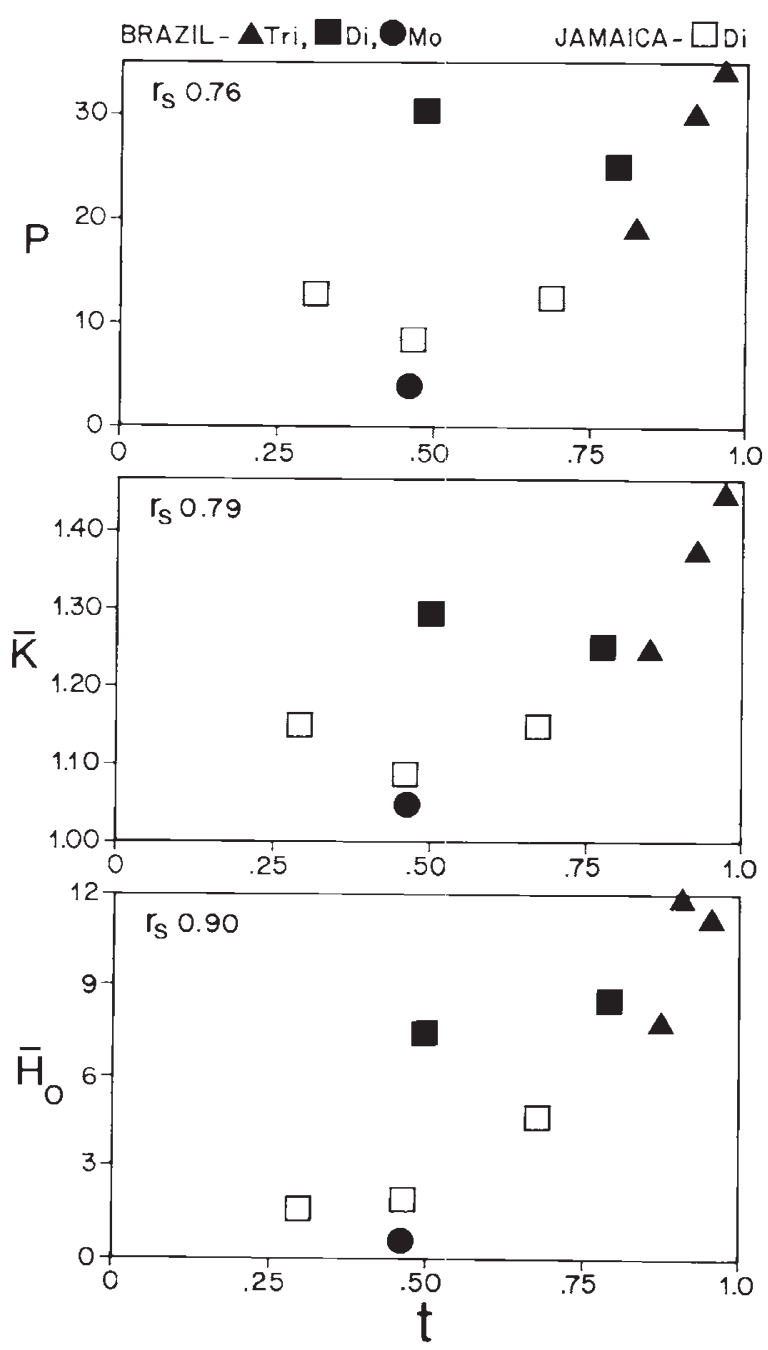

Figure 2 The relationship between outcrossing rate $(t)$ and several population genetic parameters $(P=$ proportion of loci polymorphic, $\bar{K}=$ mean number of alleles per locus, $\bar{H}_{0}=$ mean observed heterozygosity in populations of Eichhornia paniculata from N.E. Brazil and Jamaica.

individuals. Thus there is an overall heterozygote deficiency when Brazilian populations are treated as a panmictic unit. $\hat{F}$ would be equal to $\hat{f}$ if populations were representative of the region as a whole, and differentiation was negligible. However, in Brazil, the magnitude of $\hat{\theta}$ almost entirely explains the overall correlation and indicates that population differentiation is pronounced. The contribution due to the average correlation of genes within individuals (within populations), $\hat{f}$, is minor. Brazilian populations, on average, are slightly less heterozygous than expected under Hardy-Weinberg equilibrium. In 
Table 4 Estimates of gene correlation for populations of Eichhornia paniculata in N.E. Brazil and Jamaica. The parameters are related to $F$-statistics such that $F=F_{I T}, \theta=F_{\mathrm{SI}}$, and $f=F_{I S}$

\begin{tabular}{lcccc}
\hline & No. of loci & $\hat{F}(\text { S.E. })^{*}$ & $\hat{\theta}(\text { S.E. })^{*}$ & $\hat{f}(\text { S.E. })^{*}$ \\
\hline All populations & 12 & $0.574(0.014)$ & $0 \cdot 528(0 \cdot 014)$ & $0.096(0.005)$ \\
Brazilian populations & 10 & $0.384(0.009)$ & $0 \cdot 324(0.010)$ & $0.088(0.005)$ \\
Jamaican populations & 3 & $0.734(0.009)$ & $0.633(0.009)$ & $0.275(0.041)$ \\
\hline
\end{tabular}

* The variance was estimated by jackknifing across loci, following the method of Miller (1974).

contrast, in Jamaica, $\hat{F}=0.734$, and a significant component is explained by differences among populations $(\hat{\theta}=0.633)$, but a significant within individual (within population) correlation is also evident $(\hat{f}=0 \cdot 275)$ (table 4$)$. Within Jamaican populations, on average, heterozygotes are deficient.

When the amount of inbreeding is known, the observed fixation index can be compared with $F_{e}$, the expectation at inbreeding equilibrium, when the mating system is the only factor causing inbreeding. $F_{e}=(1-t) /(1+t)$ and is the inbreeding coefficient expected at equilibrium with an outcrossing rate $t$. The difference is $\Delta F$ as given in Brown (1979). Positive values of $\Delta F$ indicate a heterozygote deficiency while negative values indicate an excess of heterozygotes, in comparison with inbreeding equilibrium expectation $(\Delta F=0)$. For each region, the mean $\Delta F$ is close to panmictic expectation. Thus, in Jamaica, the average deficiency of heterozygotes $(\hat{f}=0 \cdot 275)$ is accounted for by selfing. In fact, on average, a small excess of heterozygotes is observed. However, individual populations in both regions are heterogeneous. Populations B10 and J14 have a deficit of heterozygotes, and populations B9 and J15 have an excess of heterozygotes (table 5). A number of factors can contribute to a deficit of heterozygotes (Brown, 1979); the most likely are (a) population substructuring with regard to allele frequency, and (b) restricted neighbourhood size with near neighbour mating. Excess of heterozygotes may be attributed to selection at the marker locus (or genes linked to it).

\section{Gene diversity}

The mean total gene diversity for Brazilian populations is more than twice that of Jamaican populations $\left(\bar{H}_{T}=0 \cdot 15\right.$ and $\bar{H}_{T}=0 \cdot 06$, respectively; table 6). The within population component $\bar{H}_{S}$, also known as the "expected heterozygosity", or "Nei's gene diversity", is the mean proportion of loci at which a given individual can be expected to be heterozygous. $\bar{H}_{S}=0.09$ for Brazilian populations and $\bar{H}_{S}=0.03$ for Jamaican populations (table 6). Genetic diversity is significantly correlated with outcrossing frequency in the nine populations for which $t$ has been estimated $\left(r_{\mathrm{s}}=0 \cdot 85, n=9, p=\right.$ 0.004).

In addition to differences between Brazil and Jamaica in the total gene diversity, the partitioning of variation into population components differs between the two regions. The amount of diversity among Brazilian populations is smaller $\left(\bar{G}_{S T}=\right.$ $0 \cdot 40)$ than for Jamaican populations $\left(\bar{G}_{S T}=0.57\right)$ (table 6). In Jamaica, more diversity is spread between populations $\left(\bar{R}_{S T}=1 \cdot 70\right)$, while in Brazil more variation is contained within populations $\left(\bar{R}_{S T}=0.81\right)$.

Nei's genetic distance (Nei, 1972) is calculated from allele frequencies across all loci, and all pairs of populations are compared. Values range from 0 to $\infty, 0$ between populations that share all alleles at the same frequency, and $\infty$ between populations that have no alleles in common. The average genetic distance between Brazilian populations was $\bar{d}=0.085$ and $\bar{d}=0.049$ for Jamaican populations. The data illustrate the effect of including

Table 5 Comparison of $\hat{f}$ with $\hat{F}_{v^{\prime}}$ in nine populations of Eichhornia paniculata from N.E. Brazil and Jamaica

\begin{tabular}{|c|c|c|c|c|}
\hline Population & $\begin{array}{l}\text { No. of } \\
\text { loci }\end{array}$ & $\hat{f}$ & $\hat{F}$ & $\Delta F$ \\
\hline \multicolumn{5}{|l|}{ Brazil } \\
\hline B5 & 7 & 0.038 & $0 \cdot 010$ & 0.028 \\
\hline B7 & 6 & $0 \cdot 112$ & 0.087 & 0.025 \\
\hline B11 & 6 & $0 \cdot 046$ & 0.031 & 0.015 \\
\hline $\mathrm{B} 9$ & 6 & $0 \cdot 234$ & $0 \cdot 342$ & $-0 \cdot 108$ \\
\hline B10 & 5 & $0 \cdot 267$ & 0.129 & $0 \cdot 138$ \\
\hline \multirow[t]{2}{*}{$\mathrm{B} 8$} & 2 & 0.366 & $0 \cdot 361$ & 0.005 \\
\hline & & & Mean & $0 \cdot 017$ \\
\hline \multicolumn{5}{|l|}{ Jamaica } \\
\hline $\mathrm{J} 15$ & 3 & $0 \cdot 209$ & 0.550 & $-0 \cdot 341$ \\
\hline $\mathrm{J} 14$ & 3 & 0.339 & $0 \cdot 190$ & $0 \cdot 149$ \\
\hline \multirow[t]{2}{*}{$\mathrm{J} 12$} & 2 & 0.329 & $0 \cdot 361$ & -0.032 \\
\hline & & & Mean & -0.075 \\
\hline
\end{tabular}


Table 6 Gene diversity in Eichhornia paniculata from N.E. Brazil and Jamaica. Except where noted, six populations were included for Brazil and five for Jamaica

\begin{tabular}{|c|c|c|c|c|c|c|c|c|}
\hline \multirow[b]{2}{*}{ Locus } & \multicolumn{2}{|c|}{$H_{T}$} & \multicolumn{2}{|c|}{$H_{S}$} & \multicolumn{2}{|c|}{$G_{S \gamma^{-}}$} & \multicolumn{2}{|c|}{$R_{S T}$} \\
\hline & Brazil & Jamaica & Brazil & Jamaica & Brazil & Jamaica & Brazil & Jamaica \\
\hline DIA-1 & $0 \cdot 17$ & 0.00 & 0.12 & 0.00 & $0 \cdot 25$ & - & $0 \cdot 40$ & - \\
\hline GDH-1 & $0 \cdot 30$ & 0.00 & $0 \cdot 20$ & 0.00 & 0.34 & - & 0.61 & - \\
\hline MDH-2 & $0 \cdot 12^{*}$ & 0.00 & $0 \cdot 11^{*}$ & 0.00 & $0 \cdot 12^{*}$ & - & $0 \cdot 17^{*}$ & - \\
\hline MDH-3 & $0 \cdot 17$ & 0.00 & $0 \cdot 11$ & 0.00 & $0 \cdot 36$ & - & 0.67 & - \\
\hline PER-1 & 0.47 & 0.00 & $0 \cdot 29$ & 0.00 & 0.38 & - & 0.75 & - \\
\hline PGD-1 & 0.04 & 0.00 & 0.04 & 0.00 & $0 \cdot 10$ & - & $0 \cdot 14$ & - \\
\hline GOT-1 & 0.00 & 0.36 & 0.00 & $0 \cdot 14$ & - & 0.62 & - & $2 \cdot 07$ \\
\hline GOT-2 & $0 \cdot 00$ & 0.49 & 0.00 & 0.21 & - & 0.58 & - & $1 \cdot 70$ \\
\hline GOT-3 & 0.47 & 0.00 & $0 \cdot 30$ & 0.00 & $0 \cdot 36$ & - & 0.68 & - \\
\hline PGM-1 & 0.63 & 0.49 & 0.26 & $0 \cdot 23$ & 0.56 & 0.54 & 1.71 & 1.47 \\
\hline ACP-2 & $0 \cdot 20$ & 0.00 & 0.15 & 0.00 & $0 \cdot 23$ & - & $0 \cdot 36$ & - \\
\hline PGI-2 & $0 \cdot 38$ & 0.00 & 0.22 & 0.00 & 0.43 & - & 0.89 & - \\
\hline PGI-3 & $0 \cdot 49^{* *}$ & 0.00 & $0 \cdot 16^{* *}$ & $0 \cdot 00$ & $0.68^{* *}$ & - & $4 \cdot 29^{* *}$ & - \\
\hline Mean & $0 \cdot 15$ & 0.06 & 0.09 & 0.03 & 0.40 & 0.57 & 0.81 & $1 \cdot 70$ \\
\hline
\end{tabular}

* Population B11 was not included because of difficulties of interpretation.

** Populations B5, B9 and B10 contained a null allele at this locus and were therefore not included in the analysis.

monomorphic loci in the genetic distance function. Jamaican populations have a larger proportion of their variation between populations $\left(\vec{R}_{S T}=1 \cdot 71\right.$; table 6), and a larger among population component of the overall fixation index $(\hat{\theta}=0.633$; table 4$)$, than Brazilian populations $\left(R_{S T}=0.81\right.$; table $6 ; \theta=0 \cdot 324$; table 4 ). But because the total amount of diversity is small in Jamaica, the genetic distance between populations is less than that between Brazilian populations. The average genetic distance between Jamaican and Brazilian populations is $0 \cdot 267$. An unweighted pair group method cluster analysis of genetic distance presented as a dendrogram illustrates the distinctness of Brazilian and Jamaican populations (fig. 3).

To determine if an association of geographic and genetic distance between populations within Brazil and Jamaica occurs, a significance test was performed using a non-parametric measure of

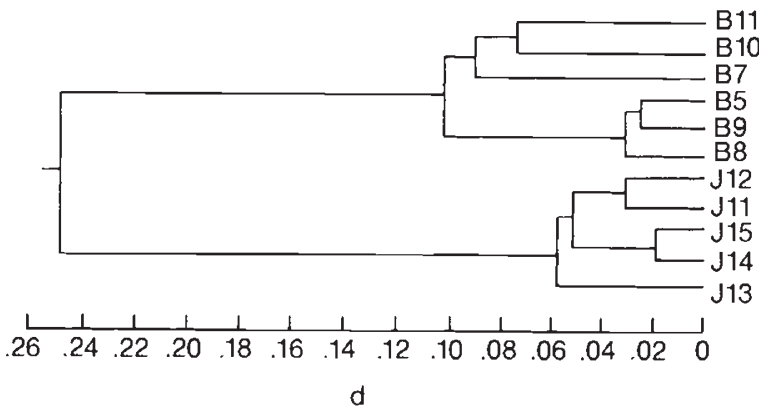

Figure 3 UPGMA clustering based on Nei's genetic distance (d) among populations of Eichhornia paniculata from N.E. Brazil and Jamaica. association (Dietz, 1983). The test statistic, $K_{c}$, is a measure of association of two matrices (genetic distance and geographic distance) and the significance is determined by generating a probability distribution of $K_{c}$, under the null hypothesis of no association, based on all possible permutations of the matrices (Dietz, 1983). No association between genetic and geographic distance was detected in either region; for Brazil, $K_{c}=-4(p=0 \cdot 325, n s)$, and for Jamaica $K_{c}=-11(p=0 \cdot 186, n s)$.

\section{DISCUSSION}

To interpret the causes responsible for the amount and pattern of genetic variation within and among populations of $E$. paniculata, two overriding factors need to be considered. The first involves the evolutionary history of the species in the Caribbean and the probability that colonisation of Jamaica involved a genetic bottleneck. The second concerns the evolutionary breakdown of tristyly to semihomostyly in the species and its effect on altering the mating system of populations from outcrossing to selfing. These processes acting in concert or alone can result in changes in the genetic structure of populations; the discussion will therefore consider their relative importance.

When populations are founded by a small number of individuals, and subsequent growth is slow, the genetic consequences are a reduction in average heterozygosity and loss of alleles (Nei et al., 1975). Since genetic bottlenecks may be expected during island colonisation, we may anticipate 
a reduction in the genetic variation of island populations, particularly in plant species such as Eichhornia paniculata, which commonly exhibit relatively small population sizes (Barrett, 1985a, b). In this study it was found that on the island of Jamaica, E. paniculata is depauperate with respect to allozyme variability, at both regional and poulational levels. Values for $\bar{H}_{T}, \bar{H}_{S}$ and $\bar{K}$ were significantly lower than those from N.E. Brazil.

Owing to island isolation, a restricted number of dispersal events is probably the most important factor determining the reduction in total allozyme diversity of $E$. paniculata populations in Jamaica. Support for this view comes from comparisons of genetic variation between plant populations that are geographically marginal but not necessarily isolated from populations at the centre of the range. Relative to source populations, peripheral populations can be either less heterozygous (Rick et al., 1977; Yeh and Layton, 1979; Guries and Ledig, 1982), equally heterozygous (Levin, 1977, 1978), or more heterozygous (Harding and Mankinen, 1972; Jain and Martins, 1979; Bosbach and Hurka, 1981) than those that occupy the centre of the range. However, where insular populations have been compared with mainland populations, gene diversity has been found to be reduced or completely absent (Rick and Fobes, 1975; and see Schwaegerle and Schaal, 1979).

The origins and evolutionary history of $E$. paniculata in the Caribbean region are uncertain. The occurrence of all three style morphs in N.E. Brazil and the presence of close tristylous relatives in the region suggest that E. paniculata may have originated in lowland tropical South America (Barrett, 1985a). If this is true, it seems reasonable to postulate that the Caribbean concentration of populations is a derived centre. The direct source region for Jamaica and the time of colonisation are, however, unknown. The neighbouring island of Cuba would seem to be the most likely primary source, following early establishment of $E$. paniculata in Central America and the Caribbean from lowland S. America. Studies of the genetic structure of Cuban populations of E. paniculata would be useful in evaluating this suggestion. The occurrence of several isozyme alleles in Jamaica that were not detected in the survey of Brazilian populations supports the view that E. paniculata has a long history in the Caribbean and, unlike its close relative, the water hyacinth (E. crassipes), is not a recent immigrant to the region (Barrett, 1979).

Self-fertilisation is common in colonising plant species (Baker, 1955; Brown and Marshall, 1981; Price and Jain, 1981). As a consequence, it is often difficult to separate the effects of genetic bottlenecks and levels of inbreeding on gene diversity. The expected consequence of self-fertilisation on the genetic structure of populations is to decrease heterozygosity within populations, allowing selection to operate on homozygous lines (Jain, 1976). Loss of alleles and a reduction in polymorphic loci are secondary responses to drift, selection and contraints on gene flow. Empirical evidence relating plant mating systems to genetic variability at the species level are for the most part consistent with these expectations. The surveys conducted by Hamrick et al. (1979), Brown (1979), Gottlieb (1981) and Loveless and Hamrick (1984) have all found a general reduction in the number of alleles per locus, the per cent of loci polymorphic and various indices of genetic diversity in primarily selfing as opposed to primarily outcrossing species. In addition, studies of closely related species with contrasting mating systems have also revealed patterns in accord with the survey data (Gottlieb, 1973; Brown and Jain, 1979; Levin, 1978; Layton and Ganders, 1984). Few within-species comparisons have been made that quantify both the mating system and the level and distribution of gene diversity in plant populations. In some studies, a positive correlation has been demonstrated between measures of genetic variation and outcrossing rate (Rick et al., 1977; 1979; Schoen, 1982), whereas in others no association was found (Jain, 1978; Yeh and Layton, 1979; Ganders et al., 1985). In E. paniculata the per cent of loci polymorphic, mean number of alleles per locus, mean observed heterozygosity and gene diversity were all significantly correlated with outcrossing rate. However, it should be noted that this association is strongly influenced by differences in the amount of genetic variation between populations in Brazil and Jamaica so that caution is required in interpreting the results. A larger sample of populations from Brazil with contrasting mating systems is required to fully establish the relationship between mating behaviour and genetic variation within populations.

A shift towards self-fertilisation can increase the distribution of genetic variation among populations as a result of drift and local selection. In $E$. paniculata, values for the inter- to intra-population ratio of gene diversity indicate that in Jamaica a greater proportion of the gene diversity is distributed between populations than is contained within them. Although the reverse pattern occurs in Brazil, in absolute terms Brazilian populations are more differentiated than those in Jamaica $\left(\bar{D}_{S T}=0.059\right.$ and $\bar{D}_{S T}=0.033$ for Brazil and Jamaica, respectively). These data are in accord 
with the survey of Brown (1979) who found that inbreeders exhibited about five times the diversity of outbreeders relative to their intra-population variation, or about twice the level in terms of absolute $\left(\bar{D}_{S T}\right)$ values.

The genetic structure of E. paniculata populations observed on the island of Jamaica can be ascribed to (a) genetic bottleneck(s), (b) selffertilisation and (c) drift and/or selection following colonisation. It is not possible to rule out the contribution of any of these mechanisms. However, some evidence suggests that neither genetic bottlenecks nor self-fertilisation alone could produce the levels and patterns of variation observed in $E$. paniculata populations. A genetic bottleneck would not explain the difference between Brazil and Jamaica in the partitioning of genetic diversity among populations. Differentiation within Jamaica is governed by factors subsequent to the founding of populations on the island.

The importance of self-fertilisation can be examined by comparing populations from the two regions that share similar mating systems. Dimorphic populations in Brazil and Jamaica displayed overlapping ranges in estimates of outcrossing frequency; $t=0.49,0.77$ in Brazil; $t=0.29,0.47$, 0.68 in Jamaica, yet measures of allelic richness, observed heterozygosity and gene diversity were consistently higher in all dimorphic Brazilian populations than dimorphic Jamaican populations. Similarly, monomorphic (containing only $\mathrm{M}$ individuals) Jamaican populations were invariant electrophoretically, whereas the single monomorphic Brazilian population was variable at DIA-1 and PGI-3. These data, while limited, suggest that when the effect of mating system is roughly accounted for, Jamaican populations possess substantially less genetic variability at allozyme loci than their Brazilian counterparts. This difference probably reflects the contrasting evolutionary histories of populations in the two regions.

Acknowledgements We thank Joel Shore and George Sidrak for aid in field collections, Tony Brown, Jim Eckenwalder, Norman Ellstrand, Kermit Ritland, and Bruce Weir for constructive criticism of the manuscript, and the Natural Sciences and Engineering Research Council of Canada for funding the research.

\section{REFERENCES}

AVISE. J. C. SMITH, M. H., SELANDER, R. K., LAWLOR. T. E. AND RAMSEY, P. R. 1974. Biochemical polymorphism and systematics in the genus Peromyscus, V: Insular and mainland species of the subgenus Hapolomyomys. Syst. Zool., $23,226-238$.
AYALA, F. J., POWELl, J. R. AND DOBZHANSKY, T. 1971. Enzyme variability in the Drosophila willistoni group. II. Polymorphisms in continental and island populations of Drosophila willistoni. Proc. Nat. Acad. Sci. U.S.A., 68, 24802483.

BAKER, H. G. 1955. Self-compatibility and establishment after "long-distance" dispersal. Evolution, 9, 347-348.

BARRETT, S. C. H. 1979. The evolutionary breakdown of tristyly in Eichhornia crassipes (Mart.) Solms (Water Hyacinth). Evolution, 33, 449-510.

BARRETT, S. C. H. 1985a. Floral trimorphism and monomorphism in continental and island populations of Eichhornia paniculata (Spreng.) Solms. (Pontederiaceae). Biol. J. Linn. Soc., 25, 41-60.

BARRETT, S. C. H. 1985b. Ecological genetics of breakdown in tristyly. In Haeck, J. and J. W. Woldendorp (eds.) Structure and Functioning of Plant Populations 2: Phenotypic and Genotypic Variation in Plant Populations. North-Holland Publishing Company, Amsterdam, pp. 267-275.

BARRETT, S. C. H., BROWN, A. H. D. AND SHORE, J. S. 1987. Disassortative mating in tristylous Eichhornia paniculata (Pontederiaceae). Heredity, 58, 49-55.

BOSBACH, K. AND HURKA, H. 1981. Biosystematic studies on Capsella bursa-pastoris (Brassicaceae): Enzyme poly morphism in natural populations. Plant Syst. and Evol. 137, 73-94.

BROWN, A. H. D. 1979. Enzyme polymorphism in plant populations. Theor. Pop. Biol., 15, 1-42.

BROWN, A. H. D. AND MARSHALL, D. R. 1981. Evolutionary changes accompanying colonization in plants. In Scudder, G. C. E. and Reveal, J. L. (Eds.) Evolution Today. CarnegieMellon University, Pittsburgh, pp. 351-363.

BROWN, C. R. AND JAIN, S. K. 1979. Reproductive system and pattern of genetic variation in two Limnanthes species. Theor. and Appl. Genet., 54, 181-190.

CARDY, B. J., STUBER, C. W. AND GOODMAN, M. M. 1981. Techniques for starch gel electrophoresis of enzymes from maize (Zea mays L.). Institute of Statistics Mimeograph Series No. 1317, North Carolina State University, Raleigh, $31 \mathrm{pp}$.

CARlQuist, s. 1974. Island Biology. Columbia Press, New York.

CLARKE, C. A. AND SHEPPARD, P. M. 1963. Interactions between major genes and polygenes in the determination of the mimetic patterns of Papilio dardanus. Evolution, 17, 404-413.

COCKERHAM, C. C. 1969. Variance of gene frequencies. Evolution, 23, 72-84.

COCKERHAM, C. C. 1973. Analysis of gene frequencies. Genetics, 74, 679-700.

DARLINGTON, P. J., JR. 1957. Zoogeography. John Wiley and Sons, New York.

DIETZ, E. J. 1983. Permutation tests for association between two distance matrices. Syst. Zool., 32, 21-26.

DOBZHANSKY, T. 1957. Genetics of natural populations. XXVI Chromosome variability in island and continental populations of Drosophila willistoni from Central America and the West Indies. Evolution, 11, 280-293.

GANDERS, F. R., DENNY, S. E. AND TSAI, D. 1985. Breeding systems and genetic variation in Amsinckia spectabilis (Boraginaceae). Can. J. Bot., 66, 533-538.

GLOVER, D. E. 1985. Mating systems and genetic variation in continental and island populations of Eichhornia paniculata (Spreng.) Solms (Pontederiaceae). M.Sc. Thesis, University of Toronto.

GLOVER, D. E. AND BARRETT, S. C. H. 1986. Variation in the mating system of Eichhornia paniculata (Spreng.) Solms (Pontederiaceae). Evolution, 40, 1122-1131. 
GOTTLIEB, L. D. 1973. Enzyme differentiation and phylogeny in Clarkia franciscana, C. rubicunda and C. amoena. Evolution, 27, 205-214.

GOTTLIEB, L. D. 1981. Electrophoretic evidence and plant populations. Prog. in Phytochemistry., 7, 1-46.

GURIES, R. P. AND LEDIG, F. T. 1982. Genetic diversity and population structure in pitch pine (Pinus rigida Mill.). Evolution, 36, 387-402.

HARDING, J. AND MANKINEN, C. B. 1978. Genetics of Lupinus IV. Colonization and genetic variability in Lupinus succulentus. Theor. Appl. Genet., 42, 267-271.

HAMRICK, J. L., LINHART, Y. B. AND MITTON, J. B. 1979 Relationships between life history characters and electrophoretically detectable genetic variation in plants. Ann. Rev. Ecol. Syst., 10, 173-200.

JAIN, S. K. 1976. The evolution of inbreeding in plants. Ann. Rev. Ecol. Syst., 7, 469-495.

JAIN, S. K. AND MARTINS, P. S. 1979. Ecological genetics of the colonizing ability of rose clover (Trifolium hirtum All.). Amer. J. Bot., 66, 361-366.

LACK, D. 1976. Darwin's Finches. Cambridge University Press, Cambridge.

LAYTON, C R. AND GANDERS, F. R. 1984. The genetic consequences of contrasting breeding systems in Plectritis (Valerianaceae). Evolution, 38, 1308-1325.

LEVIN, I). A. 1977. The organization of genetic variability in Phlox drummondii. Evolution, 38, 477-494.

LEVIN, D. A. 1978. Genetic variation in annual Phlox: Selfcompatible versus self-incompatible species. Evolution, 32, 245-263.

LOVELESS, M. D. AND HAMRICK, J. L. 1984. Ecological determinants of genetic structure in plant populations. Ann. Rev. Ecol. Syst., 15, 65-95.

MACARTHUR, R. H. ANI) WILSON, E. O. 1967. The Theory of Island Biogeography. Princeton University Press, Princeton.

MILleR, R. G. 1974. The jackknife-a review. Biometrika, 61, $1-15$.

MITTON, J. B., LINHART, Y. B., HAMRICK, J. L. AND BECKMAN, J. S. 1977. Observations on the genetic structure and mating system of ponderosa pine in the Colorado front range. Theor. Appl. Genet., 51, 5-13.

NEI, M. 1972. Genetic distance between populations. Amer. Natur., 106, 283-292.

NEI, M. 1973. Analysis of gene diversity in subdivided populations. Proc. Nat. Acad. Sci., 70, 3321-3323.
NEI, M. AND ROYCHOUDHURY, A. K. 1974. Sampling variances of heterozygosity and genetic distance. Genetics, 76, 379390.

NeI, M., MARUYAMA, T. AND CHAKRABORTY, R. 1975. The bottleneck effect and genetic variability in populations. Evolution, 29, 1-10.

PRICE, S. C. AND JAIN, S. K. 1981. Are inbreeders better colonizers? Oecologia, 49, 283-286.

RICK, C. M. AND FOBES, J. F. 1975. Allozymes of Galapagos tomatoes: Polymorphism, geographic distribution and affinities. Evolution, 29, 443-457.

RICK, C. M., FOBES, J. F. AND HOLLE, M. 1977. Genetic variation in Lycopersicon pimpinellifolium: evidence of evolutionary change in mating systems. Pl. Syst. Evol, 127, 139-170.

RICK, C. M., FOBES, J. F. AND TANKSLEY, S. D. 1979. Evolution of mating systems in Lycopersicon hirsutum as deduced from genetic variation in electrophoretic and morphological characters. Pl. Syst. Evol., 132, 279-298.

SCANIDALIOS, J. G. 1969. Genetic control of molecular forms of isozymes in plants-a review. Biochem. Genet., 3, 37-39.

SCHOEN, D. J. 1982. Genetic.variation and the breeding system of Gilia achilleifolia. Evolution, 36, 361-370.

SCHWAEGERLE, K. E. AND SCHAAL, B. A. 1979. Genetic variability and founder effect in the pitcher plant Sarracenia purpurea L. Evolution, 33, 1210-1218.

SHAW, C. R. AND PRASAD, R. 1970. Starch gel electrophoresis of enzymes-A compilation of recipes. Biochem. Genet., 3, 207-320.

VALlEJoS, C. E. 1983, Enzyme activity staining. In Tanksley, S. D. and Orton, T. J. (Eds.) Isozymes in Plant Genetics and Breeding. Part A. Elsevier Science Publishers, B.V. Amsterdam, pp. 469-515.

WEIR, B. S. AND COCKERHAM, C. C. 1984. Estimating $F$-statistics for the analysis of population structure. Evolution, 38, 1358-1370.

WILliamson, M. 1981. Island Populations. Oxford University Press, Oxford.

Wright, S. 1951. The genetical structure of populations. Ann. Eugen., 15, 313-354.

YEH, F.C. AND LAYTON, C.R. 1979. The organization of genetic variability in central and marginal populations of lodgepole pine Pinus contorta spp. Latifolia. Can. J. Genet. Cytol., $11,487-503$ 
Appendix Allele frequencies for thirteen polymorphic loci surveyed in eleven populations of Eichhornia paniculata from N.E. Brazil (B) and Jamaica (J). Locus " 1 " represents the most anodally migrating locus for a system. Allele " $a$ " represents the most anodally migrating allele at a locus. Sample size $(\mathrm{N})$ is given for each locus and population

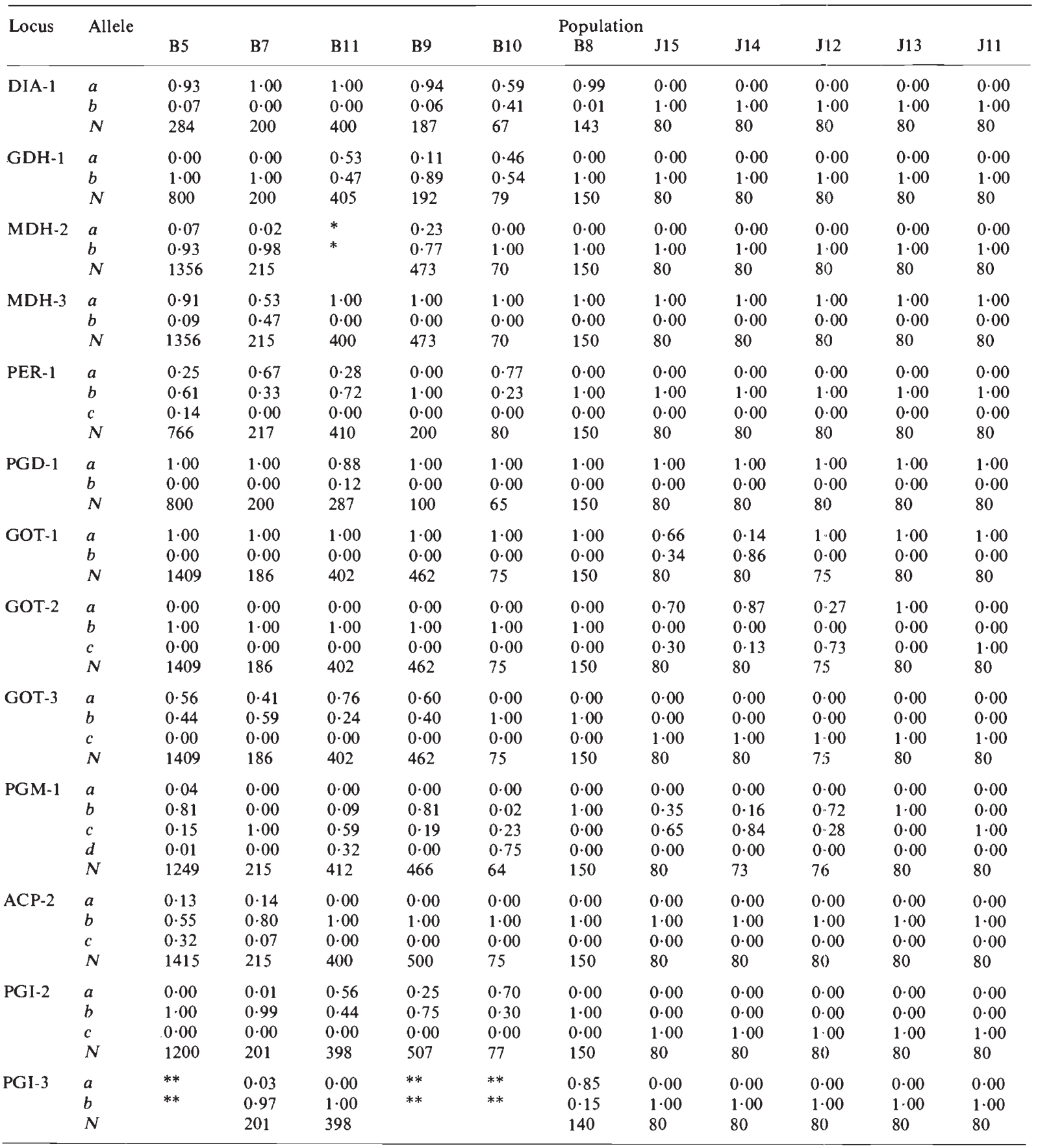

\footnotetext{
* Due to interpretation difficulties, MDH-2 was not scored in this population.
}

** A null allele was present at this locus in these populations. Heterozygotes could not be distinguished. 